\title{
Evaluasi Jaringan Drainase Kecamatan Tanjung Kabupaten Lombok Utara
}

(Evaluation of Drainage Channels at Tanjung Sub-districts North Lombok Regency)

\author{
Ari Ramadhan Hidayat ${ }^{1}$ \\ ${ }^{1}$ Prodi Teknik Sipil, Fakultas Teknik, Universitas Muhammadiyah Mataram
}

\section{ARTICLE INFO}

Article history

Received : 11 Agustus 2021

Revised : 17 September 2021

Accepted : 22 September 2021

DOI :

https://doi.org/10.33366/rekabua na.v6i2.2693

Keywords :

capacity of canal; drainage; evaluation

e- mail corresponding author : ari.utara82@gmail.com

\section{ABSTRAK}

Kabupaten Lombok Utara berada di sebelah utara kaki Gunung Rinjani. Terdiri dari lima kecamatan yakni Kecamatan Pemenang, Tanjung, Gangga, Kayangan, dan Bayan dengan total jumlah penduduk 220.412 jiwa. Meskipun menjadi kabupaten termuda, banyak permasalahan yang dihadapi, salah satunya permasalahan lingkungan, seperti banjir dan genangan. Ketika musim penghujan terjadi genangan di beberapa lokasi di Kecamatan Tanjung. Hal ini disebabkan oleh sitem drainase yang ada tidak berfungsi dengan baik. Berdasarkan latar belakang di atas, dilakukan penelitian untuk mengetahui kondisi saluran eksisting, faktor penyebab terjadinya genangan dan upaya apa yang sesuai untuk menanggulangi permasalahan banjir dan genangan di Kecamatan Tanjung Kabupaten Lombok Utara. Metode yang digunakan dalam penelitian ini adalah dengan melakukan observasi dan survey di lapangan. Hasil dari analisi diketahui bahwa permasalahan banjir dan genangan di Kecamatan Tanjung Kabupaten Lombok Utara dipengaruhi oleh kondisi alam dan aktivitas manusia. Upaya yang dapat dilakukan saat ini adalah dengan melakukan redesain dan perbaikan pada dinding-dinding saluran yang mengalami kerusakan serta membersihkan saluran drainase dari tumpukan sedimentasi dan sampah.
\end{abstract}

\section{PENERBIT}

\section{UNITRI PRESS}

Jl. Telagawarna, TlogomasMalang, 65144, Telp/Fax: $0341-565500$

\section{cc) (†) (D)}

This is an open access article under the Creative Commons Attribution-ShareAlike $\quad 4.0$ International License. Any further distribution of this work must maintain attribution to the author(s) and the title of the work, journal citation and DOI CC-BY-SA

\section{ABSTRACT}

North Lombok Regency is located north of the below of Mount Rinjani where this area consists of five sub-districts, i.e., Pemenang, Tanjung, Gangga, Kayangan, and Bayan sub-districts, with a total population of 220,412 people. Despite being the youngest district, it has many problems, one of which is environmental problems, such as flooding and inundation. During the rainy season, inundation occurs in several locations in Tanjung District. Inundation happens because the existing drainage system is not functioning correctly. Based on the background mentioned before, a study was conducted to determine the condition of the existing channel, the factors causing inundation, and appropriate actions to overcome the problem of flooding and inundation in Tanjung District, North Lombok Regency. The method used in this research is to make observations and surveys in the field. From the analysis results, it is known that the problems of flooding and inundation in Tanjung District, North Lombok Regency are influenced by natural conditions and human activities. The solution or action that can be taken is to redesign and repair the damaged canal walls and clean the drainage channels from sediment and pile of trash.

Cara Mengutip : Hidayat, A.R. (2021) Evaluasi Jaringan Drainase Kecamatan Tanjung Kabupaten Lombok Utara. 


\section{PENDAHULUAN}

Kabupaten Lombok Utara merupakan salah satu kabupaten dari sepuluh kabupaten/kota di Nusa Tenggara Barat (NTB), dan menjadi kabupaten termuda. Kabupaten Lombok Utara berada di sebelah utara kaki Gunung Rinjani. Terdiri dari lima kecamatan yakni Kecamatan Pemenang, Tanjung, Gangga, Kayangan, dan Bayan dengan total jumlah penduduk 220.412 jiwa [1]

Sebagai kabupaten yang baru terbentuk, banyak terjadi pembangunan di Kabupaten Lombok Utara. Salah satunya di Kecamatan Tanjung yang merupakan ibu kota dari Kabupaten Lombok Utara. Sebagian besar aktivitas perkantoran berlangsung di Kecamatan Tanjung. Akibatnya banyak lahan terbuka hijau yang dialih fungsikan sebagai gedung perkantoran. Peningkatan jumlah penduduk setiap tahunnya juga ikut mempengaruhi alih fungsi lahan yang terjadi di Kecamatan Tanjung.

Hasil survey di lapangan, terdapat beberapa titik genangan di kawasan Kecamatan Tanjung. Gambar di bawah ini menunjukan kondisi genang di Lapangan Tioq Tata Tunaq Kecamatan Tanjung Kabupaten Lombok Utara pada saat musim penghujan.

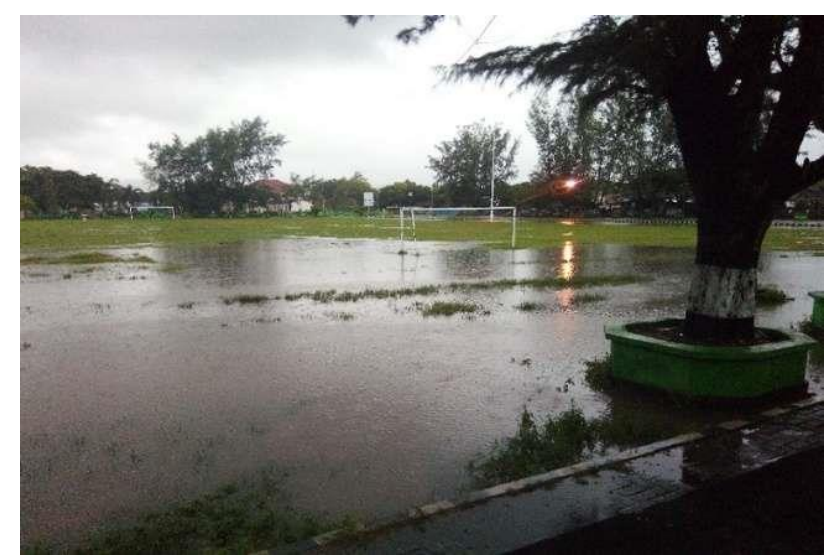

\section{Gambar 1. Kondisi genangan di Lapangan Tioq Tata Tunaq}

Sumber: Hasil Survey

Tujuan dari penelitian ini adalah untuk mengetahui kondisi eksisting jaringan drainase di Kecamatan Tanjung. Selain itu, dalam penelitian ini juga akan mencari penyebab terjadinya genangan di beberapa titik di Kecamatan Tanjung dan upaya penanggulangannya.

Secara umum drainase dapat diartikan sebagai suatu upaya untuk mengalirkan air yang berasal dari air hujan, air irigasi maupun air limbah domestik dan sebagainya ke lokasi yang terendah. Jika sistem drainase ini dapat berfungsi dengan baik akan dapat mecegah genangan air pada suatu kota atau wilayah [2]. Sedangkan drainase perkotaan adalah ilmu drainase yang mengkhususkan pengkajiannya pada kawasan perkotaan yang erat kaitannya dengan kondisi lingkungan sosial-budaya yang terdapat dikawasan kota [3]. Fungsi dari drainase adalah mengalirkan kelebihan air secepat mungkin, mencegah aliran air yang berasal dari daerah pengaliran sekitar jalan, dan mencegah kerusakan lingkungan di sekitar jalan [4]. 
Fakta di lapangan saat ini banyak jaringan drainase di beberapa daerah perkotaan yang tidak berfungsi dengan baik. Banyak faktor yang menyebabkan kurang berfungsinya jaringan drainase dengan baik, dapat berasal dari faktor alam maupun non alam.

Hasil penelitian terkait penanganan genangan pada daerah perkotaan menunjukkan beberapa permasalahan yang menyebabkan genangan diantaranya perubahan tata guna lahan [5][6], penumpukan sampah dan sedimentasi pada saluran drainase [5][7][8], pengaruh dari pasang surut[5], saluran trotoar yang tidak memiliki inlet [7], dan kurangnya pemeliharaan yang dilakukan pada saluran drainase [7][8].

Sementara itu, dari hasil beberapa penelitian tersebut beberapa upaya yang dapat dilakukan untuk mengatasi permasalahan genang diantaranya melakukan normalisasi saluran drainase, yakni dengan cara membersihkan saluraan dari tumpukan sedimentasi dan sampah [8], menerapkan eco-drainage yakni membuat beberapa titik sumur resapan [5][6], memasang pintu klep otomatis tipe Pusair Pa-Fg1 pada daerah yang terpengaruh oleh pasang surut [5], dan melakukan pemeliharaan rutin pada setiap saluran drainase [8].

\section{METODE PENELITIAN}

Wilayah studi (Kecamatan Tanjung) secara administrasi merupakan wilayah Kabupaten Lombok Utara yang secara geografis terletak di belahan selatan bumi atau katulistiwa, yaitu berada diantara $116^{\circ} 5^{\prime}$ - $116^{\circ} 16^{\prime}$ Bujur Timur dan $8^{\circ} 20^{\prime}-8^{\circ} 28^{\prime}$ Lintang Selatan. Batas-batas wilayah studi secara administrasi adalah sebagai berikut:

- Sebelah Utara berbatasan dengan Laut Jawa.

- Sebelah Timur berbatasan dengan Kecamatan Gangga.

- Sebelah Selatan berbatasan dengan Kecamatan Narmada dan Kecamatan Gunung Sari.

- Sebelah Barat berbatasan dengan Kecamatan Pemenang.

Luas Kecamatan Tanjung mencapai 11.564 ha (14,28\% dari total luas Kabupaten Lombok Utara). Kecamatan Tanjung terdiri dari 7 (tujuh) desa swakarsa dan beribukota kecamatan di Desa Tanjung.

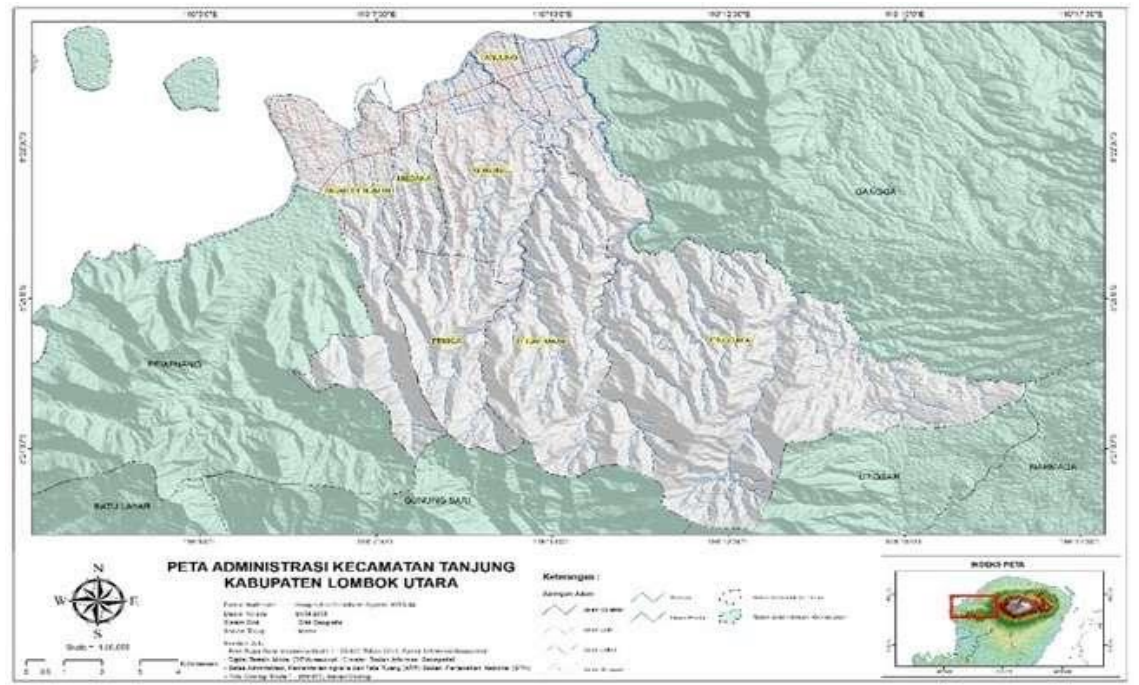

Gambar 2. Peta Administrasi Kecamatan Tanjung

Sumber:Dinas PUPR Kabupaten Lombok Utara 
Terdapat beberapa tahapan yang akan dilalui di dalam penelitian ini diantaranya sebagai berikut:

\section{Persiapan}

Tahap persiapan yakni melakukan studi literatur dan indentifikasi permasalahan pada lokasi penelitian.

\section{Pengumpulan data}

Data-data yang dibuthkan di dalam penelitian ini berupa data sekunder dan data primer, yakniyakni sebagai berikut:
a. Data curah hujan
b. Data topografi
c. Data saluran drainasi eksisting

\section{Analisis data}

a. Analisis Hidrologi

- Analisis hujan rerata daerah

- Analisis hujan rancangan

- Analisis debit rencana

b. Analisis Kapasitas saluran eksisting

Analisa kapasitas saluran berdasarkan hasil survey lapangan dengan memasukkan dimensi saluran drainase eksisting.

\section{Analisis Hidrologi}

\section{a. Curah Hujan Rata-rata}

Salah satu metode yang biasa digunakan dalam menghitung hujan rerata daerah adalah metode rerata aritmatik (aljabar). Metode ini yang paling sederhana dalam perhitungan curah hujan daerah. Hujan daerah diperoleh dari persamaan berikut [9]:

$$
p=\frac{p_{1}+p_{2}+p_{3}+\cdots+p_{n}}{n}=\sum_{i=1}^{n} \frac{p_{i}}{n}
$$

Dengan :

$$
\begin{array}{ll}
p & =\text { tinggi curah hujan rata-rata areal }(\mathrm{mm}), \\
p_{1}, p_{2}, p_{3}, \ldots, p_{n} & =\text { tinggi curah hujan pada pos penakar } 1,2,3, \ldots, \mathrm{n}(\mathrm{mm}), \\
n & =\text { banyaknya pos penakaran }
\end{array}
$$

\section{b. Hujan Rencana}

\section{Analisis distribusi frekuensi}

Dalam statistik dikenal beberapa jenis distribusi (agihan) frekuensi dan yang banyak digunakan dalam hidrologi yaitu[10] :

1. Distribusi normal

$$
X_{T}=\bar{X}+K_{T} S
$$

\section{Dengan:}

$X_{T} \quad=$ perkiraan nilai yang diharapkan pada T-tahunan

$\bar{X} \quad=$ nilai rata-rata sampel

$K_{T} \quad=$ Faktor Frekuensi

$\mathrm{s} \quad=$ Standar deviasi 
2. Distribusi log-normal

$Y_{T}=\overline{\mathrm{Y}}+K_{T} S$

Dengan:

$Y_{T} \quad=$ perkiraan nilai yang terjadi pada T-tahunan

$\overline{\mathrm{Y}} \quad=$ nilai rata-rata sampel

$K_{T} \quad=$ Faktor Frekuensi

3. Distribusi gumbel

$X=\bar{X}+s K$

Dengan:

$X \quad=$ perkiraan nilai yang diharapkan pada $\mathrm{T}$-tahunan

$\bar{X} \quad=$ nilai rata-rata sampel

$K=$ Faktor Frekuensi

$\mathrm{S} \quad=$ Standar deviasi

4. Distribusi log-pearson III

$\log X_{T}=\overline{\log X}+K_{T} \times S \log X$

Dengan:

$\log X_{T} \quad=$ Nilai logaritmis hujan rencana dengan periode ulang $\mathrm{T}$ tahun

$\overline{\log X}=$ nilai rata-rata dari $\log X$

$S \log X=$ Deviasi standar $\log \mathrm{X}$

$K_{T} \quad=$ Variabel standar, besarnya tergantung koefisien kepencengan

\section{Analisis Uji kesesuaian distribusi}

Uji distribusi probabilitas dimaksudkan untuk mengetahui apakah persamaan distribusi probabilitas yang dipilih dapat mewakili distribusi statistik sampel data yang dianalisis. Metode Smirnov Kolmogorov merupakan salah satu metode yang bisa digunakan untuk menganalisis uji kesesuaian distribusi. Adapun Langkah-langkah analisis menggunakan metode Smirnov Kolmogorov adalah sebagai berikut[10]:

1. Mengurutkan data dari besar ke kecil atau sebaliknya.

2. Menentukan peluang empiris $\mathrm{P}(\mathrm{Xi})$ dengan rumus tertentu (Weibull, Hazen, Grinngorten, Bloom, Cunane).

3. Menentukan peluang teoritis berdasarkan persamaan distribusi probabilitas yang dipilih (Gumbel, normal, log Normal, Log person-III).

4. Menghitung selisih $(\Delta \mathrm{P})$ antara peluang empiris dan teoritis untuk setiap data yang sudah diurut.

$\Delta \mathrm{Pi}=\mathrm{P}(\mathrm{Xi})-\mathrm{P}^{\prime}(\mathrm{Xi})$

Jika $\Delta \mathrm{Pi}<\Delta \mathrm{P}$ kritis maka distibusi probabilitas yang dipilih dapat diterima.

\section{Intensitas curah hujan}

Intensitas curah hujan adalah ketinggian curah hujan yang terjadi pada sautu kurun waktu dimana air tersebut terkonsentrasi. Perhitungan intensitas curah hujan menggunakan persamaan Mononobe sebagai berikut [11]: 
Dengan :

$$
I_{t}=\frac{R_{24}}{24}\left(\frac{24}{t}\right)^{\frac{2}{3}}
$$

$I_{t} \quad=$ Intensitas Curah hujan ( $\left.\mathrm{mm} / \mathrm{jam}\right)$

$R_{24}=$ Curah hujan maksimum selam 24 jam (mm)

$\mathrm{t} \quad=$ Lamanya curah hujan (jam)

\section{Perhitungan waktu konsentrasi}

Untuk saluran didaerah perkotaan, nilai tc adalah waktu yang dibutuhkan oleh air untuk mengalir diatas permukaan tanah sampai ke saluran terdekat (to) ditambah waktu aliran air didalam saluran (ts) sampai ke titik yang ditinjau. Dengan menggunakan rumus :

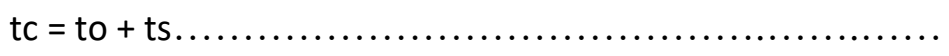

Perhitungan to untuk panjang daerah pengaliran kurang dari $400 \mathrm{~m}$ digunakan persamaan :

$$
\begin{aligned}
& \text { to }=0,0195\left(\frac{\mathrm{L}}{\sqrt{\mathrm{S}}}\right)^{0,77} \\
& t s=\frac{L}{v} \ldots \ldots \ldots \ldots \ldots \ldots \ldots
\end{aligned}
$$

Dengan :

to = waktu aliran permukaan (menit).

$\mathrm{L}$ = panjang antara titik terjauh dengan inlet atau titik yang ditinjau (m).

$\mathrm{S}=$ kemiringan rerata permukaan tanah.

ts = waktu aliran di saluran (menit).

$\mathrm{v}=$ kecepatan aliran di saluran $(\mathrm{m} / \mathrm{det})$.

\section{c. Analisis debit rancangan}

Untuk memperoleh debit banjir rancangan dalam saluran drainase digunakan metode rasional [12] :

$$
\mathrm{Q}=0,278 \times \mathrm{C} \times \mathrm{I} \times \mathrm{A}
$$

Dengan :

$\mathrm{Q}=$ debit banjir maksimum $\left(\mathrm{m}^{3} / \mathrm{dt}\right)$

$\mathrm{C}=$ koefisien pengaliran

I = intensitas hujan rerata selama waktu tiba banjir ( $\mathrm{mm} / \mathrm{jam})$

A = luas daerah pengaliran $\left(\mathrm{km}^{2}\right)$

\section{Analisis Hidrolika}

Analisis hidrolika dilakukan untuk melakukan evaluasi terhadap saluran drainase ekesisting berdasarkan debit banjir hasil Analisa. Secara umum, bentuk saluran drainase berupa saluran terbuka. Analisis hidrolika untuk saluran terbuka dapat menggunakan persamaan Manning, sebagai berikut[13]:

$$
\mathrm{Q}=\mathrm{V} \times \mathrm{A}
$$




$$
V=\frac{1}{n} x R^{\frac{2}{3}} x S^{\frac{1}{2}}
$$

Dengan:

$\mathrm{Q}=$ Debit saluran $\left(\mathrm{m}^{3} / \mathrm{dt}\right)$

$\mathrm{V}=$ Kecepatan aliran $(\mathrm{m} / \mathrm{dt})$

$\mathrm{A}=$ Luas penampang saluran $\left(\mathrm{m}^{2}\right)$

$\mathrm{R}=$ Jari-jari hidrolis $(\mathrm{m})$

$\mathrm{P}=$ Keliling penampang basah $(\mathrm{m})$

$\mathrm{n}=$ angka kekasaran Manning

\section{HASIL DAN PEMBAHASAN}

Sistem jaringan drainase di Kecamatan Tanjung tersebar dibeberapa titik pemukiman dan ruas jalan. Sistem jaringan drainase yang ada saat ini masih mengandalkan saluran irigasi sekaligus sebagai saluran drainase dan saluran limbah rumah tangga (gray water). Dalam penelitian ini yang akan dianalisis adalah titik-titik yang mengalami genangan saat musim penghujan. Gambar berikut menunjukkan titi-titik di Kecamatan Tanjung yang mengalami genangan saat musim penghujan.
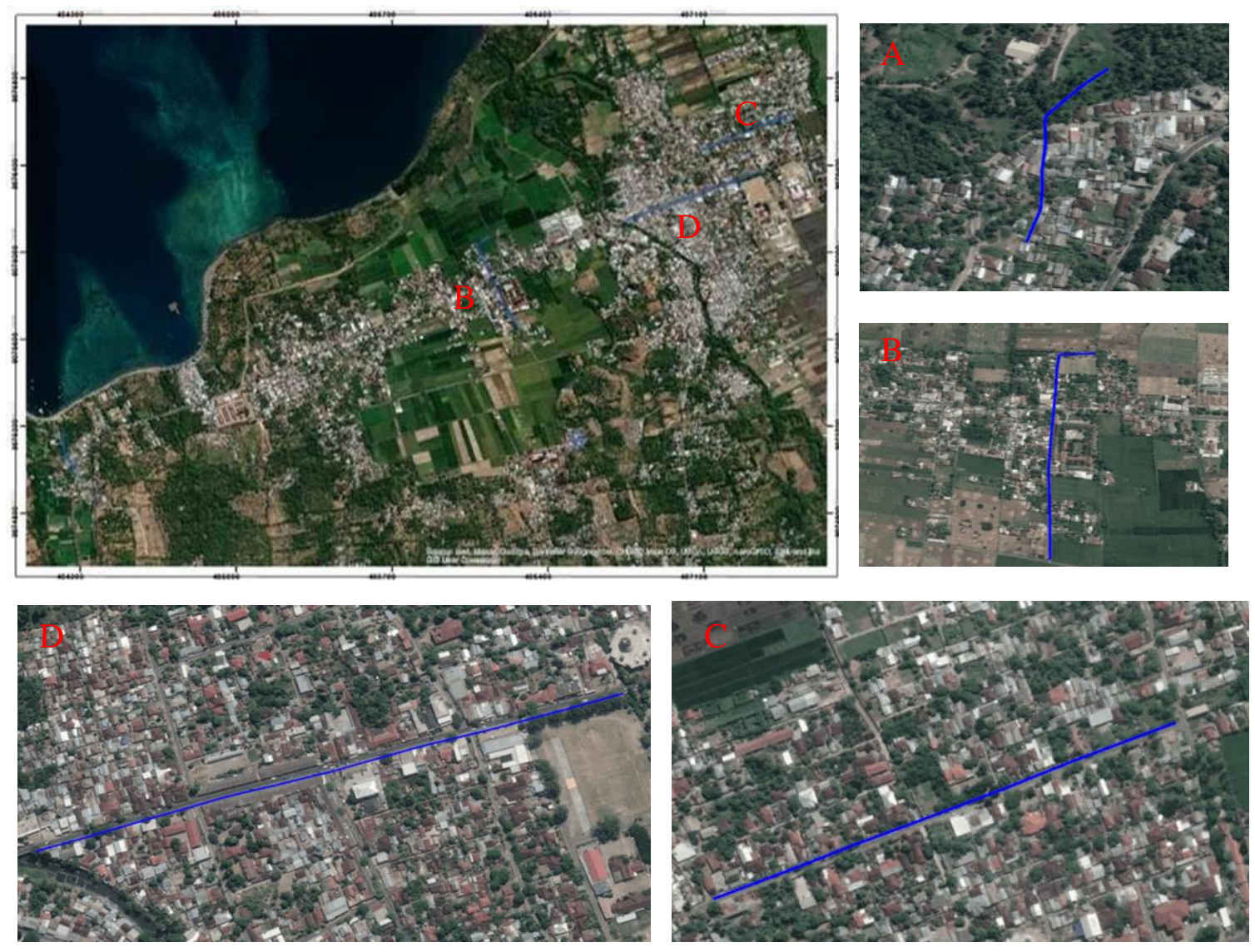

Gambar 3. Layout Saluran Eksisting Drainase Kecamatan Tanjung 


\section{Analisis hujan rerata daerah}

Data curah hujan yang dipakai yakni data hujan harian maksimum tahunan dari 1 (satu) stasiun hujan terdekat, yaitu Stasiun Santong. Jumlah series data yang digunakan yaitu dari tahun 1990-2018. Analisis hujan rerata daerah menggunakan metode rerata aljabar. Hal ini disebabkan oleh stasiun hujan yang terdekat dengan lokasi studi hanya satu stasiun hujan.

Tabel 1. Data Hujan Maksimum Harian Tahunan Sta. Santong

\begin{tabular}{cccccc}
\hline No & Tahun & $\begin{array}{c}\text { hujan max } \\
(\mathbf{m m})\end{array}$ & No & Tahun & hujan max $(\mathbf{m m})$ \\
\hline $\mathbf{1}$ & 2018 & 189,1 & 16 & 2003 & 98,1 \\
\hline $\mathbf{2}$ & 2017 & 147,9 & 17 & 2002 & 183 \\
\hline $\mathbf{3}$ & 2016 & 161,4 & 18 & 2001 & 67 \\
\hline $\mathbf{4}$ & 2015 & 118 & 19 & 2000 & 98,9 \\
\hline $\mathbf{5}$ & 2014 & 173,5 & 20 & 1999 & 122,2 \\
\hline $\mathbf{6}$ & 2013 & 226,5 & 21 & 1998 & 120 \\
\hline $\mathbf{7}$ & 2012 & 189,3 & 22 & 1997 & 140 \\
\hline $\mathbf{8}$ & 2011 & 87 & 23 & 1996 & 107 \\
\hline $\mathbf{9}$ & 2010 & 112,7 & 24 & 1995 & 74,5 \\
\hline $\mathbf{1 0}$ & 2009 & 112,7 & 25 & 1994 & 152,8 \\
\hline $\mathbf{1 1}$ & 2008 & 114,4 & 26 & 1993 & 80,5 \\
\hline $\mathbf{1 2}$ & 2007 & 135,8 & 27 & 1992 & 157,1 \\
\hline $\mathbf{1 3}$ & 2006 & 220 & 28 & 1991 & 227,9 \\
\hline $\mathbf{1 4}$ & 2005 & 83,5 & 29 & 1990 & 182,7 \\
\hline $\mathbf{1 5}$ & 2004 & 182,2 & & & \\
\hline
\end{tabular}

Analisis hujan rerata daerah menggunakan persamaan rerata aljabar. Dari hasil analisis didapatkan nilai hujan rerata daerah sebesar 140,20 mm.

\section{Analisa Curah Hujan Rancangan}

Besaran curah hujan rancangan dalam studi ini ditetapkan berdasarkan perancangan dengan periode ulang 2, 5, 10, 25, 50, 100 dan 1.000 .

\section{Analisa distribusi frekuensi}

Sebelum menentukan metode curah hujan rancangan, terlebih dahulu dilakukan analisa distribusi frekuensi untuk memilih metode yang tepat dan memenuhi kriteria perhitungan curah hujan maksimum rencana dengan menggunakan beberapa metode yang ada yaitu Metode Normal, Metode Log Normal, Metode Gumbel, dan dengan Metode Log Pearson III. Untuk hasil perhitungan disajikan dalam table berikut ini.

Tabel 2. Hasil Perhitungan Hujan Rencangan

\begin{tabular}{cccccccccc}
\hline \multirow{2}{*}{$\begin{array}{c}\text { Probabilitas } \\
\begin{array}{c}\text { Sesuai } \\
\text { Urutan }\end{array}\end{array}$} & Kala & \multicolumn{6}{c}{ Karakteristik Hujan (mm) Menurut Probabilitasnya } \\
\cline { 3 - 11 } & & \multicolumn{2}{c}{ Normal } & \multicolumn{2}{c}{ Log Normal } & \multicolumn{2}{c}{ Gumbel } & \multicolumn{2}{c}{ Log Pearson III } \\
\hline $\mathbf{P}(\mathbf{x}>=\mathbf{X})$ & $\mathbf{T}$ (tahun) & $\mathbf{K}_{\mathbf{T}}$ & $\mathbf{X}_{\mathbf{T}}$ & $\mathbf{K}_{\mathbf{T}}$ & $\mathbf{X}_{\mathbf{T}}$ & $\mathbf{K}_{\mathbf{T}}$ & $\mathbf{X}_{\mathbf{T}}$ & $\mathbf{K}_{\mathbf{T}}$ & $\mathbf{X}_{\mathbf{T}}$ \\
\hline $50,00 \%$ & 2 & 0,000 & 140,197 & $-0,163$ & 132,584 & $-0,164$ & 132,525 & 0,034 & 134,136 \\
\hline $20,00 \%$ & 5 & 0,842 & 179,499 & 0,794 & 177,296 & 0,719 & 173,794 & 0,850 & 177,795 \\
\hline $10,00 \%$ & 10 & 1,282 & 200,043 & 1,417 & 206,382 & 1,305 & 201,117 & 1,258 & 204,694 \\
\hline
\end{tabular}




\begin{tabular}{rcrrrrrrrr}
\hline $4,00 \%$ & 25 & 1,751 & 221,950 & 2,194 & 242,673 & 2,044 & 235,641 & 1,679 & 236,749 \\
\hline $2,00 \%$ & 50 & 2,054 & 236,103 & 2,768 & 269,445 & 2,592 & 261,252 & 1,944 & 259,411 \\
\hline $1,00 \%$ & 100 & 2,326 & 248,832 & 3,337 & 296,038 & 3,137 & 286,674 & 2,177 & 281,165 \\
\hline $0,10 \%$ & 1.000 & 3,090 & 284,504 & 5,251 & 385,390 & 4,936 & 370,677 & 2,806 & 349,376 \\
\hline
\end{tabular}

\section{Uji Kesesuaian Distribusi}

Untuk mengetahui suatu kebenaran hipotesa distribusi frekuensi, maka dilakukan pemeriksaan uji kesesuaian distribusi, dalam hal ini menggunakan dua metode uji yaitu uji Smirnov Kolmogorov. Hasil Analisa dapat dilihat pada tabel 3 di bawah ini.

Tabel 3. Hasil Pengujian distribusi probabilitas dengan Metode Smirnov-Kolmogorov

\begin{tabular}{|c|c|c|c|c|c|c|c|c|c|c|}
\hline \multirow{2}{*}{$\begin{array}{c}\text { Hujan } \\
(\mathbf{m m})\end{array}$} & \multirow{2}{*}{$\mathbf{m}$} & \multirow{2}{*}{$\mathbf{m} /(\mathbf{N}+1)$} & \multicolumn{2}{|c|}{ 1. Normal } & \multicolumn{2}{|c|}{ 2. Log Normal } & \multicolumn{2}{|c|}{ 3. Gumbel } & \multicolumn{2}{|c|}{ 4. Log Pearson III } \\
\hline & & & $\mathbf{P}(\mathbf{x}>=\mathbf{X})$ & $\Delta \mathbf{P}$ & $\mathbf{P}(\mathbf{x}>=\mathbf{X})$ & $\Delta \mathbf{P}$ & $\mathbf{P}(\mathbf{x}>=\mathbf{X})$ & $\Delta \mathbf{P}$ & $\mathbf{P}(\mathbf{x}>=\mathbf{X})$ & $\Delta \mathbf{P}$ \\
\hline 227,90 & 1 & 0,033 & 0,030 & 0,003 & 0,058 & 0,025 & 0,049 & 0,016 & 0,052 & 0,019 \\
\hline 226,50 & 2 & 0,067 & 0,032 & 0,034 & 0,060 & 0,006 & 0,051 & 0,016 & 0,054 & 0,013 \\
\hline 220,00 & 3 & 0,100 & 0,044 & 0,056 & 0,071 & 0,029 & 0,061 & 0,039 & 0,065 & 0,035 \\
\hline 189,30 & 4 & 0,133 & 0,147 & 0,013 & 0,151 & 0,018 & 0,136 & 0,002 & 0,150 & 0,017 \\
\hline 189,10 & 5 & 0,167 & 0,147 & 0,019 & 0,152 & 0,015 & 0,136 & 0,030 & 0,151 & 0,016 \\
\hline 183,00 & 6 & 0,200 & 0,180 & 0,020 & 0,175 & 0,025 & 0,159 & 0,041 & 0,176 & 0,024 \\
\hline 182,70 & 7 & 0,233 & 0,181 & 0,052 & 0,177 & 0,057 & 0,160 & 0,073 & 0,177 & 0,056 \\
\hline 182,20 & 8 & 0,267 & 0,184 & 0,082 & 0,179 & 0,088 & 0,162 & 0,104 & 0,180 & 0,087 \\
\hline 173,50 & 9 & 0,300 & 0,238 & 0,062 & 0,218 & 0,082 & 0,201 & 0,099 & 0,222 & 0,078 \\
\hline 161,40 & 10 & 0,333 & 0,325 & 0,008 & 0,284 & 0,049 & 0,269 & 0,064 & 0,292 & 0,041 \\
\hline 157,10 & 11 & 0,367 & 0,359 & 0,008 & 0,312 & 0,055 & 0,297 & 0,069 & 0,321 & 0,046 \\
\hline 152,80 & 12 & 0,400 & 0,394 & 0,006 & 0,341 & 0,059 & 0,328 & 0,072 & 0,351 & 0,049 \\
\hline 147,90 & 13 & 0,433 & 0,434 & 0,001 & 0,376 & 0,058 & 0,365 & 0,068 & 0,387 & 0,046 \\
\hline 140,00 & 14 & 0,467 & 0,502 & 0,035 & 0,437 & 0,029 & 0,431 & 0,035 & 0,450 & 0,016 \\
\hline 135,80 & 15 & 0,500 & 0,538 & 0,038 & 0,472 & 0,028 & 0,469 & 0,031 & 0,486 & 0,014 \\
\hline 122,20 & 16 & 0,533 & 0,650 & 0,117 & 0,593 & 0,060 & 0,602 & 0,068 & 0,606 & 0,072 \\
\hline 120,00 & 17 & 0,567 & 0,667 & 0,101 & 0,614 & 0,047 & 0,624 & 0,057 & 0,625 & 0,059 \\
\hline 118,00 & 18 & 0,600 & 0,683 & 0,083 & 0,632 & 0,032 & 0,644 & 0,044 & 0,643 & 0,043 \\
\hline 114,40 & 19 & 0,633 & 0,710 & 0,076 & 0,665 & 0,032 & 0,680 & 0,047 & 0,675 & 0,042 \\
\hline 112,70 & 21 & 0,700 & 0,722 & 0,022 & 0,681 & 0,019 & 0,697 & 0,003 & 0,690 & 0,010 \\
\hline 112,70 & 21 & 0,700 & 0,722 & 0,022 & 0,681 & 0,019 & 0,697 & 0,003 & 0,690 & 0,010 \\
\hline 107,00 & 22 & 0,733 & 0,761 & 0,028 & 0,733 & 0,001 & 0,753 & 0,019 & 0,740 & 0,006 \\
\hline 98,90 & 23 & 0,767 & 0,812 & 0,045 & 0,802 & 0,035 & 0,825 & 0,059 & 0,805 & 0,038 \\
\hline 98,10 & 24 & 0,800 & 0,816 & 0,016 & 0,808 & 0,008 & 0,832 & 0,032 & 0,811 & 0,011 \\
\hline 87,00 & 25 & 0,833 & 0,873 & 0,039 & 0,889 & 0,055 & 0,911 & 0,078 & 0,886 & 0,053 \\
\hline 83,50 & 26 & 0,867 & 0,888 & 0,021 & 0,910 & 0,043 & 0,930 & 0,064 & 0,906 & 0,039 \\
\hline 80,50 & 27 & 0,900 & 0,899 & 0,001 & 0,926 & 0,026 & 0,945 & 0,045 & 0,921 & 0,021 \\
\hline
\end{tabular}




\begin{tabular}{|c|c|c|c|c|c|c|c|c|c|c|}
\hline 74,50 & 28 & 0,933 & 0,920 & 0,013 & 0,952 & 0,019 & 0,967 & 0,034 & 0,947 & 0,014 \\
\hline 67,00 & 29 & 0,967 & 0,941 & 0,025 & 0,976 & 0,009 & 0,985 & 0,018 & 0,971 & 0,004 \\
\hline \multicolumn{3}{|c|}{ Hitungan kelayakan } & $\Delta \mathbf{M a x}=$ & $\mathbf{0 , 1 1 7}$ & $\Delta \mathbf{M a x}=$ & $\mathbf{0 , 0 8 8}$ & $\Delta \operatorname{Max}=$ & 0,104 & $\Delta \operatorname{Max}=$ & 0,087 \\
\hline \multicolumn{2}{|c|}{$\Delta$ Kritik $=$} & 0,246 & & diterima & & diterima & & diterima & & diterima \\
\hline
\end{tabular}

Berdasarkan analisis distribusi frekuensi dan uji kesesuai distribusi, distribusi Log Person-III memiliki $\Delta$ Max paling kecil $(0,087)$. Sehingga untuk hujan rancangan digunakan distribusi Log Person-III dengan kala ulang 5 tahun yaitu $\mathrm{Rc}=177,80 \mathrm{~mm}$.

\section{Analisis Debit Rancangan}

Analisis debit rancangan menggunakan persamaan rasional. Nilai koefisien pengaliran (C) yang digunakan yaitu 0,5. Hal ini berdasarkan lokasi jaringan drainase yang berada di kawasan perumahan (rumah tinggal)[10]. Hasil perhitungan disajikan pada tabel di bawah ini.

Tabel 4. Hasil Perhitungan Debit rencana

\begin{tabular}{|c|c|c|c|c|c|c|c|c|}
\hline $\begin{array}{c}\text { Nama } \\
\text { Saluran }\end{array}$ & Lokasi & $\mathbf{L}(\mathbf{m})$ & $\begin{array}{c}\mathrm{I} \\
(\mathrm{mm} / \mathbf{j a m})\end{array}$ & $\mathbf{C}$ & $\begin{array}{c}\text { Ts } \\
\text { (menit) }\end{array}$ & $\begin{array}{c}\text { Tc } \\
\text { (menit) }\end{array}$ & Cs & $\begin{array}{c}\text { Qranc } \\
\text { (m3/dt) }\end{array}$ \\
\hline \multicolumn{9}{|c|}{ SALURAN SEKUNDER TANJUNG-SUNGAI SOKONG } \\
\hline SS. TNJ 1 & JL. R Tanjung & 112,000 & 569,977 & 0,5 & 0,179 & 2,141 & 0,960 & 0,939 \\
\hline SS. TNJ 2 & JL. R Tanjung & 120,000 & 437,475 & 0,5 & 0,296 & 3,183 & 0,956 & 0,502 \\
\hline SS. TNJ 3 & JL. R Tanjung & 40,500 & 960,098 & 0,5 & 0,066 & 0,980 & 0,967 & 0,280 \\
\hline SS. TNJ 4 & JL. R Tanjung & 70,500 & 479,846 & 0,5 & 0,249 & 2,771 & 0,957 & 0,351 \\
\hline SS. TNJ 5 & JL. R Tanjung & 67,000 & 731,157 & 0,5 & 0,112 & 1,474 & 0,963 & 0,548 \\
\hline SS. TNJ 6 & JL. R Tanjung & 81,000 & 635,574 & 0,5 & 0,146 & 1,818 & 0,961 & 0,596 \\
\hline SS. TNJ 7 & JL. R Tanjung & 29,000 & 785,202 & 0,5 & 0,128 & 1,324 & 0,954 & 0,207 \\
\hline SS. TNJ 8 & JL. R Tanjung & 58,000 & 740,795 & 0,5 & 0,119 & 1,445 & 0,960 & 0,141 \\
\hline \multicolumn{9}{|c|}{ SALURAN SKUNDER KARANG BEDIL 1 KI } \\
\hline SS. KRBK 1 & Kr. Bedil & 89,000 & 116,023 & 0,5 & 2,068 & 23,282 & 0,957 & 0,085 \\
\hline SS. KRBK 2 & Kr. Bedil & 60,000 & 133,789 & 0,5 & 2,899 & 12,111 & 0,893 & 0,038 \\
\hline SS. KRBK 3 & Kr. Bedil & 53,200 & 297,424 & 0,5 & 0,486 & 3,656 & 0,938 & 0,219 \\
\hline \multicolumn{9}{|c|}{$\begin{array}{l}\text { SALURAN SEKUNDER GUBUK BARU SOKONG } \\
\end{array}$} \\
\hline SS. GBBS 1 & GB. Baru Sokong & 112,400 & 341,598 & 0,5 & 0,649 & 4,612 & 0,934 & 0,183 \\
\hline SS. GBBS 2 & GB. Baru Sokong & 49,000 & 441,989 & 0,5 & 0,401 & 3,134 & 0,940 & 0,124 \\
\hline SS. GBBS 3 & GB. Baru Sokong & 1117,600 & 81,349 & 0,5 & 9,177 & 39,646 & 0,896 & 0,049 \\
\hline SS. GBBS 4 & GB. Baru Sokong & 35,100 & 413,779 & 0,5 & 0,566 & 3,460 & 0,924 & 0,088 \\
\hline SS. GBBS 5 & GB. Baru Sokong & 60,000 & 321,359 & 0,5 & 0,903 & 5,055 & 0,918 & 0,229 \\
\hline SS. GBBS 6 & GB. Baru Sokong & 64,000 & 315,870 & 0,5 & 0,933 & 5,187 & 0,918 & 0,175 \\
\hline \multicolumn{9}{|c|}{ TELUK DALEM KREN } \\
\hline SS. TDK 1 & TD Kren & 21,100 & 278,986 & 0,5 & 0,894 & 6,248 & 0,933 & 0,038 \\
\hline SS. TDK 2 & TD Kren & 15,000 & 750,135 & 0,5 & 0,114 & 1,418 & 0,961 & 0,105 \\
\hline SS. TDK 3 & TD Kren & 60,000 & 274,090 & 0,5 & 0,663 & 6,416 & 0,951 & 0,053 \\
\hline SS. TDK 4 & TD Kren & 26,000 & 529,164 & 0,5 & 0,191 & 2,393 & 0,962 & 0,093 \\
\hline SS. TDK 5 & TD Kren & 26,500 & 517,541 & 0,5 & 0,213 & 2,474 & 0,959 & 0,161 \\
\hline SS. TDK 6 & TD Kren & 15,000 & 677,310 & 0,5 & 0,128 & 1,653 & 0,963 & 0,377 \\
\hline
\end{tabular}




\section{Analisis Kapasitas Saluran Rencana}

Analisis kapasitas saluran digunakan untuk mengetahui kapasitas saluran eksisting untuk menampung debit rancangan berdasarkan hasil analisis sebelumnya. Hasil analisis kapasitas saluran eksisting ditampilkan pada table berikut.

Tabel 5. Analisis Kapasitas Saluran Eksisting

\begin{tabular}{|c|c|c|c|c|c|c|c|}
\hline Saluran & Lokasi & $\begin{array}{c}\mathrm{A} \\
(\mathbf{m} 2)\end{array}$ & $\mathbf{P}(\mathbf{m})$ & $\mathbf{R}(\mathbf{m})$ & $\mathbf{v}(\mathbf{m} / \mathbf{d t})$ & $\begin{array}{c}Q \\
\text { saluran } \\
(\mathrm{m} 3 / \mathrm{dt})\end{array}$ & $\begin{array}{l}\text { Q Rencana } \\
\text { (m3/dt) }\end{array}$ \\
\hline \multicolumn{8}{|c|}{ SALURAN SEKUNDER- SAL. PRIMER GUBUK BARU } \\
\hline SS. TNJ 1 & JL. R Tanjung & 0,800 & 1,600 & 0,500 & 10,406 & 8,325 & 0,939 \\
\hline SS. TNJ 2 & JL. R Tanjung & 0,800 & 1,600 & 0,500 & 6,750 & 5,400 & 0,502 \\
\hline SS. TNJ 3 & JL. R Tanjung & 0,800 & 1,600 & 0,500 & 10,156 & 8,125 & 0,280 \\
\hline SS. TNJ 4 & JL. R Tanjung & 0,800 & 1,600 & 0,500 & 4,725 & 3,780 & 0,351 \\
\hline SS. TNJ 5 & JL. R Tanjung & 0,800 & 1,600 & 0,500 & 9,996 & 7,997 & 0,548 \\
\hline SS. TNJ 6 & JL. R Tanjung & 0,800 & 1,600 & 0,500 & 9,257 & 7,406 & 0,596 \\
\hline SS. TNJ 7 & JL. R Tanjung & 0,800 & 1,600 & 0,500 & 3,784 & 3,027 & 0,207 \\
\hline SS. TNJ 8 & JL. R Tanjung & 1,100 & 2,000 & 0,550 & 8,116 & 8,928 & 0,141 \\
\hline \multicolumn{8}{|c|}{$\begin{array}{l}\text { SALURAN SKUNDER KARANG BEDIL } 1 \text { KI } \\
\end{array}$} \\
\hline SS. KRBK 1 & Kr. Bedil & 0,520 & 1,300 & 0,400 & 0,717 & 0,373 & 0,085 \\
\hline SS. KRBK 2 & Kr. Bedil & 0,160 & 0,800 & 0,200 & 0,345 & 0,055 & 0,038 \\
\hline SS. KRBK 3 & Kr. Bedil & 0,720 & 1,600 & 0,450 & 1,825 & 1,314 & 0,219 \\
\hline \multicolumn{8}{|c|}{ SALURAN SEKUNDER GUBUK BARU SOKONG } \\
\hline SS. GBBS 1 & GB. Baru Sokong & 0,450 & 1,000 & 0,450 & 2,886 & 1,299 & 0,183 \\
\hline SS. GBBS 2 & GB. Baru Sokong & 0,450 & 1,000 & 0,450 & 2,038 & 0,917 & 0,124 \\
\hline SS. GBBS 3 & GB. Baru Sokong & 0,450 & 1,000 & 0,450 & 2,030 & 0,913 & 0,049 \\
\hline SS. GBBS 4 & GB. Baru Sokong & 0,300 & 1,000 & 0,300 & 1,034 & 0,310 & 0,088 \\
\hline SS. GBBS 5 & GB. Baru Sokong & 0,300 & 1,000 & 0,300 & 1,107 & 0,332 & 0,229 \\
\hline SS. GBBS 6 & GB. Baru Sokong & 0,300 & 1,000 & 0,300 & 1,144 & 0,343 & 0,175 \\
\hline \multicolumn{8}{|c|}{ SALURAN SEKUNDER TELUK DALEM KREN } \\
\hline SS. TDK 1 & TD Kren & 0,500 & 1,000 & 0,500 & 0,393 & 0,197 & 0,038 \\
\hline SS. TDK 2 & TD Kren & 0,700 & 1,000 & 0,700 & 2,191 & 1,533 & 0,105 \\
\hline SS. TDK 3 & TD Kren & 1,080 & 1,200 & 0,900 & 1,508 & 1,628 & 0,053 \\
\hline SS. TDK 4 & TD Kren & 1,080 & 1,200 & 0,900 & 2,273 & 2,455 & 0,093 \\
\hline SS. TDK 5 & TD Kren & 0,900 & 1,200 & 0,750 & 2,073 & 1,866 & 0,161 \\
\hline SS. TDK 6 & TD Kren & 0,900 & 1,200 & 0,750 & 1,957 & 1,761 & 0,377 \\
\hline
\end{tabular}

Tabel 5 hasil analisis di atas menunjukkan bahwa kapasitas saluran eksisting masih dapat menampung air hujan yang jatuh di sekitar saluran tersebut. Genangan yang terjadi di beberapa titik system drainase Kecamatan Tanjung lebih disebabkan oleh tumpukan sampah dan sedimentasi yang menghambat aliran pada saluran tersebut.

\section{Upaya Penanggulangan Genangan}

Secara umum, kondisi sistem drainase Kecamatan Tanjung dapat digambarkan sebagai berikut : 
a. Masih banyak saluran drainase setempat dan terputus atau arah alirannya (pembuangannya) menuju ke arah daerah rawa.

b. Kapasitas saluran sudah banyak yang berkurang akibat sedimentasi dan sampah yang menumpuk di beberapa ruas saluran, sehingga mengurangi kapasitas saluran yang ada.

c. Kurangnya perhatian terhadap $\mathrm{O}$ dan $\mathrm{P}$ saluran, dimana banyak saluran yang rusak terutama penutup saluran yang mulai jebol dan menutup penampang saluran drainase.

d. Kurangnya (jumlah maupun dimensi) drain hole yang berakibat air melimpas di badan jalan dan tidak masuk ke saluran drainase.

Tabel 6. Rekapitulasi Kondisi Saluran Drainase Eksisting Kecamatan Tanjung

\begin{tabular}{|c|c|c|c|c|}
\hline No & $\begin{array}{c}\text { Lokasi } \\
\text { Genangan }\end{array}$ & Foto situasi & Kondisi Saluran Eksisting & Rekomendasi \\
\hline 1 & $\begin{array}{l}\text { Genangan } \\
\text { Jalan Raya } \\
\text { Tanjung }\end{array}$ & & $\begin{array}{l}\text { Tidak terdapat drain hole yang } \\
\text { berakibat air melimpas di badan } \\
\text { jalan dan tidak masuk ke saluran } \\
\text { drainase. Selain itu drain hole } \\
\text { eksisting berada di atas elevasi } \\
\text { jalan sehingga air menggenang } \\
\text { diatasa permukaan jalan. Kondisi } \\
\text { saluran eksisting banyak terdapat } \\
\text { sampah dan sedimentasi serta } \\
\text { lapisan penutup saluran banyak } \\
\text { yang mengalami kerusakan. }\end{array}$ & 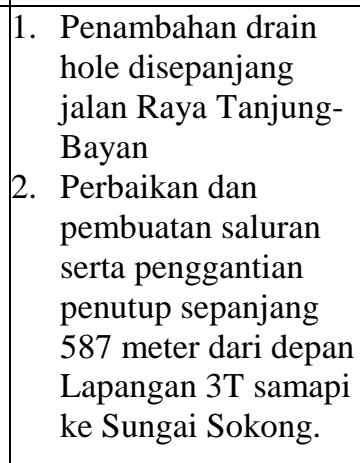 \\
\hline 2 & $\begin{array}{l}\text { Genangan } \\
\text { Jalan Karang } \\
\text { Bedil }\end{array}$ & & $\begin{array}{l}\text { Kondisi saluran sekunder di } \\
\text { kawasan karang bedil masih } \\
\text { dapat berfungsi dengan baik. } \\
\text { Namun kapasitas saluran } \\
\text { berkurang akibat adanya } \\
\text { sedimentasi dan sampah. }\end{array}$ & $\begin{array}{l}\text { normalisasi saluran } \\
\text { drainase eksisting } \\
\text { dengan melakukan } \\
\text { perbaikan pada } \\
\text { penampang saluran dan } \\
\text { pengerukan dasar } \\
\text { saluran dan mengganti } \\
\text { dengan sistem tertutup } \\
\text { karena lokasinya } \\
\text { berada kawasan } \\
\text { pertokoan. }\end{array}$ \\
\hline 3 & $\begin{array}{l}\text { Genangan } \\
\text { Gubuk Baru } \\
\text { Sokong }\end{array}$ & & $\begin{array}{l}\text { Terjadi pendangkalan akibat } \\
\text { banyaknya sedimentasi pada } \\
\text { saluran. Selain itu dinding } \\
\text { saluran banyak yang mengalami } \\
\text { kerusakan. Ujung saluran } \\
\text { drainase eksisteng berhenti di } \\
\text { depan perumahan warga. }\end{array}$ & 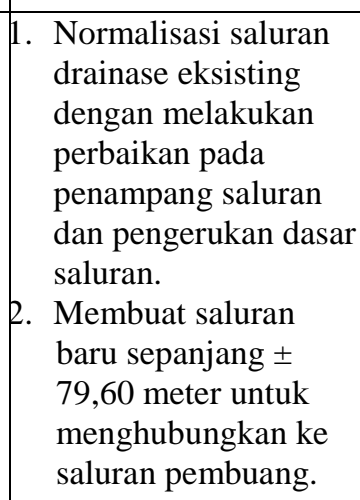 \\
\hline
\end{tabular}




\begin{tabular}{|c|c|c|c|c|}
\hline No & $\begin{array}{c}\text { Lokasi } \\
\text { Genangan }\end{array}$ & Foto situasi & Kondisi Saluran Eksisting & Rekomendasi \\
\hline 4 & $\begin{array}{l}\text { Genangan } \\
\text { Teluk Dalem } \\
\text { Kren }\end{array}$ & & $\begin{array}{l}\text { Saluran drainase di Dusun Teluk } \\
\text { Dalem Kren digunkan untuk } \\
\text { menampung air hujan dan limbah } \\
\text { rumah tangga. Kondisi saluran } \\
\text { drainase eksisting mengalami } \\
\text { pendangkalan akibat banyaknya } \\
\text { sedimentasi. Permasalahan lain } \\
\text { adalah akhir dari saluran tersebut } \\
\text { menuju muara. Jika pasir muara } \\
\text { di keruk maka wilayah tersebut } \\
\text { akan tergenang saat terjadi } \\
\text { pasang surut air laut. }\end{array}$ & $\begin{array}{l}\text { Normalisasi saluran } \\
\text { drainase eksisting } \\
\text { dengan melakukan } \\
\text { perbaikan pada } \\
\text { penampang saluran dan } \\
\text { pengerukan dasar } \\
\text { saluran. }\end{array}$ \\
\hline
\end{tabular}

\section{KESIMPULAN}

Berdasarkan hasil pembahasan di atas dapat disimpulkan bahwa kapasitas saluran drainase eksisting secara analitis masih memenuhi. Genangan yang terjadi di lapangan disebabkan oleh kondisi saluran yang tersumbat oleh sedimentasi dan sampah. Selain itu banyak lubang-lubang drain hole yang tesumbat sehingga menyebabkan genangan di sekitar saluran drainase.

Upaya yang dapat dilakukan saat ini adalah dengan melakukan redesign dan perbaikan pada dinding-dinding saluran yang mengalami kerusakan. Serta melakukan pembersihan saluran drainase akibat tumpukan sedimentasi dan sampah.

\section{DAFTAR PUSTAKA}

[1] BPS, “Kabupaten Lombok Utara Dalam Angka 2020,” Badan Pusat Statistik, Nusa Tenggara Barat, 2020.

[2] Suripin, Sistem Saluran Drainase Perkotaan Berkelanjutan. Yogyakart: Andi, 2004.

[3] H. Hasmar, Drainase Perkotaan. Yogyakarta: UII Pres, 2004.

[4] Adiwijaya, "Modul Perencanaan Drainase Permukaan Jalan,” Bandung, 2016.

[5] E. Hendrasari and U. Andawayanti, "Kajian penanganan genangan pada sub-sistem drainanse jangkok kota mataram," J. Tek. Pengair., vol. 7, pp. 17-24, 2007.

[6] R. Irawan, "Kajian penataan sistem drainase perkotaan berdasarkan rencana pola ruang," Institut Teknologi Sepuluh November, Surabaya, 2017.

[7] A. Syapawi, "Studi Permsalahan Drainase Jalan (Saluran Samping) di Lokasi Jalan Demang Lebar Daun Sepanjang \pm 3900 m,” J. Tek. Sipil, vol. 9, no. 2, pp. 143-148, 2013.

[8] E. Yulius, "Evaluasi Saluran Drainase pada Jalan Raya Sarua-Ciputat Tangerang Selatan,” BENTANG J. Teor. dan Terap. Bid. Rekayasa Sipil, vol. 6, no. 2, pp. 118130, 2018. 
[9] B. Triatmodjo, Hidrologi Terapan. Yogyakarta: Beta Offset, 2016.

[10] I. Ma. Kamiana, Teknik Perhitungan Debit Rencana Bangunan Air. Yogyakarta: Graha Ilmu, 2011.

[11] C. D. Soemarto, Hidrologi Teknik. Jakarta: Erlangga, 1999.

[12] Harto Sri BR, Hidrologi: Teori, Masalah, Penyelesaian. Yogyakarta: Nafiri, 2009.

[13] A. N. Jifa et al., "Evaluasi Saluran Drainase di Jalan Gajayana dan Jalan Sumbersari Kota Malang Evaluation of Drainage Channels at Gajayana Street and Sumbersari Street Malang," J. Sumberd. Alam dan Lingkung., pp. 9-17, 2019. 